\author{
S. Nurdavletova*, Zh. Zharmakhanova \\ L.N. Gumilyov Eurasian National University, Kazakhstan, Nur-Sultan \\ *e-mail: saniyanm83@mail.ru

\section{ANALYSIS OF THE IMPLEMENTATION \\ OF THE CENTRAL ASIA WATER\&ENERGY PROGRAM IN THE FRAMEWORK OF NEW EU STRATEGY FOR CENTRAL ASIA}

\begin{abstract}
The recently launched European Union (EU) Strategy for Central Asia is expected to continue activities that were not completed during the implementation of the previous strategy on the basis of already existing successes and achievements, gaps will be filled and cooperation in emerging new areas and spheres will be established. In the framework of the New Strategy, the Central Asia Water \& Energy Program (CAWEP) was implemented to help the Central Asian countries strengthen their energy and water security through knowledge exchange, analytical work, policy advice, and project preparation.

The article will be focused on the analysis of implementation of the CAWEP in Central Asian states. CAWEP has been implemented since 2009. Therefore, there are goals reached successfully and projects that need to be worked on further. The article will discuss how the program is being realized in each Central Asian state and what actions have already been done under the program.
\end{abstract}

Key words: CAWEP, Central Asia, European Union, World Bank.

$$
\begin{gathered}
\text { С. Нурдавлетова*, Ж. Жармаханова } \\
\text { ^.Н. Гумилев атындағы Еуразия ұлтық, университеті, Қазақстан, Нұр-Сұлтан қ. } \\
\text { *е-таil: saniyanm83@mail.ru } \\
\text { ЕО-ның Орталық Азияға арналған жаңа стратегиясы шеңберінде } \\
\text { Орталық Азия су-энергетикалық бағдарламасын іске асыруды талдау }
\end{gathered}
$$

Жақында басталған Еуропалық Одақтың (ЕО) Орталық Азияға арналған Стратегиясында қол жеткізген жетістіктер мен жетістіктерге сүйене отырып, а^дыңғы стратегияны жүзеге асыру барысында аяқталмаған іс-шаралар жалғасады деп күтілуде, олқылықтардың орны толып, дамып келе жатқан жаңа бағыттар мен салаларда ынтымақтастық орнатылады. Жаңа Стратегия шеңберінде Орталық Азия су-энергетикалық бағдарламасы (CAWEP) Орталық Азия елдерінің энергетикалық және су қауіпсіздігін білім алмасу, та^дау жұмыстары, саясат кеңестері және жобаларды дайындау арқылы нығайтуға көмектесу мақсатында жүзеге асырылды.

Мақала CAWEP-тің Орталық Азия елдерінде жүзеге асырылуын талдауға бағытталған. CAWEP 2009 жы^дан бері жұмыс істейді. Осылайша, сәтті орындалған мақсаттар бар және әрі қарай дамыту қажет ететін жобалар да бар. Мақалада Орталық Азияның әр мемлекетінде бағдарламаның қалай жүзеге асырылып жатқандығы және бағдарлама аясында қандай ісшаралар өткізілгені қарастырылады.

Түйін сөздер: CAWEP, Орталық Азия, Еуропалық, ОАақ, Аүниежүзілік Банк.

\author{
С. Нурдавлетова*, Ж. Жармаханова \\ Евразийский Национальный университет им. А.Н. Гумилева, Казахстан, г. Нур-Султан \\ *e-mail: saniyanm83@mail.ru \\ Анализ реализации водно-энергетической программы \\ Аля ЦА в рамках новой стратегии ЕС Аля Центрамьной Азии
}

\footnotetext{
Ожидается, что недавно запущенная Стратегия Европейского Союза (ЕС) Аля Центральной Азии продолжит деятельность, которая не была завершена в ходе реализации предыдущей стратегии на основе уже имеющихся успехов и достижений, пробелы будут заполнены и сотрудничество в возникающих новых областях и сферах будет установлено. В рамках Новой стратегии была реализована Центрально-Азиатская водно-энергетическая программа (CAWEP), чтобы помочь странам Центра^ьной Азии укрепить свою энергетическую и водную безопасность посредством обмена знаниями, аналитической работы, рекомендаций по вопросам политики и подготовки проектов.
} 
Статья будет посвящена анализу реализации САWEP в государствах Центральной Азии. CAWEP реализуется с 2009 года. Таким образом, есть успешно Аостигнутые цели и проекты, наА которыми необходимо работать Аальше. В статье рассматривается, как программа реализуется в каждом центральноазиатском государстве и какие действия уже были выполнены в рамках программы.

Кмючевые слова: САWEP, Центральная Азия, Европейский Союз, Всемирный банк.

\section{Introduction}

The 2007 strategy included collaboration in a wide range of areas, from regional, environmental and energy cooperation to cooperation in the security, human rights and the rule of law spheres. The first phase of regional collaboration can be described by the creation of a formal framework for communication and cooperation. These are, in particular, the annual meetings of the EU and Central Asian countries at the ministerial level, which have become a platform for the regular coordination of cooperation and clarification of its parameters. The Strategy is an ambitious framework document that brings together 10 major areas of cooperation, divided into three blocks; a "cross-cutting priority" for all areas is to promote regional cooperation in Central Asia. The radical yet realistic formulations of the Strategy point to important new developments, a broader context and the comparative advantages of partnership with the EU, as well as a positively balanced framework for cooperation.

Adopted in 2019, the new EU Strategy on Central Asia entitled "The EU and Central Asia: New Opportunities for a stronger partnership" defines three interconnected priorities on Resilienc e, Prosperity and Working together and has specific objectives on "Enhancing Environmental, Climate and Water Resilience."

Relevance of the research topic. Central Asia is a dynamically developing region with a diverse geography, sustainable economic growth and new development opportunities. An important factor on which economic growth, welfare, stability and welfare of the population depend is the rational management of its energy and water resources. Despite the growing globalization of the region, development decisions are still driven by national concerns such as food security and energy security. Competition for energy markets and expected water scarcity complicate relations between the countries of the region, climate change and population growth could exacerbate resource scarcity and relations between nations in the future (CAWEP Brochure, 2019).
The purpose of the study is to conduct a comprehensive analysis of the implementation of the program in Central Asia and identify the success and benefits of this program for the countries of Central Asia.

The methodological basis of the study was formed by general scientific and special methods of scientific cognition, in particular, synthesis, analogy, the method of system-structural analysis and content analysis.

Developed in the framework of the first EU Strategy for Central Asia, the Central Asia Water and Energy Program (CAWEP) focuses on strengthening water and energy management processes at the national and regional levels, which can contribute to income growth, poverty reduction, sustainable development, shared prosperity and increased resilience to climate change in the region. The program is a multi-donor trust fund administered by the World Bank with a total funding of US \$ 12.6 million provided (in chronological order) by the Swiss State Secretariat for Economic Affairs (SECO) (US \$ 3.5 million), Ministry international development of the UK (1.0 million US dollars) and the European Union (7.0 million euros). The structure of the third phase of the program was developed taking into account the results of the previous phases. The development target has been adjusted to enhance the focus on strengthening water security and to ensure that the necessary conditions for this are created at the regional and national levels (CAWEP Annual Report, 2019).

According to the EU Ambassador to Kazakhstan Sven-Olov Carlsson, the united regional work and resource management is vital for region's overall development and prosperity. This is due to the fact that water and energy are inevitably connected in Central Asia. Furthermore, with the help of CAWEP, the EU promotes better regional communication and cooperation on energy and water security issues. This is done in order to assist the states in improving conditions for sustainable investment and socioeconomic development (The World Bank press release, 2019). 
Analysis of the implementation of the Central Asia water\&energy program in the framework of new EU strategy ...

\section{Discussion}

The Central Asian countries are largely interdependent in their water and energy resources and environment, taking into account that they are linked by several transboundary rivers, including those flowing in the Aral sea basin, which connects all five countries. Nevertheless, it is noteworthy that distribution of energy and water resources is uneven. Moreover, hydropower resources are concentrated in the Kyrgyz Republic and Tajikistan, countries located upstream of the Amu Darya and Syr Darya rivers, while hydrocarbon resources are concentrated in Kazakhstan, Turkmenistan and Uzbekistan. The existing hydropower capacities of the Kyrgyz Republic and Tajikistan are limited by the agreed regime of summer water releases for irrigation in the lower reaches. The greatest challenges for Central Asia are the growing demand for water between Central Asian countries, provoked by huge water losses in irrigation infrastructure, causing drainage problems and increasing ecological degradation of aquatic and terrestrial ecosystems (JanuszPawletta, Gubaidullina, 2015). Another problem is the weak cooperation between the CA countries in the management of shared water resources, which can have severe economic consequences, especially in the face of increasing climate change threats. Another issue is the deficit of institutional capacity to transform policy into investment to modernize the current outdated infrastructure (Paramonov, Strokov, 2015). Lack of maintenance and limited investment in infrastructure, science and technical education resulted in a loss of technical knowledge. Improving the infrastructure and management of regional water resources to meet competing demands for human consumption, agriculture, industrial use, and power generation is vital to the economic prosperity and political stability of CA states. This gap can be partially filled with investments that must be costeffective, appropriate and environmentally sound (Berndtsson, Tussupova, 2020).

Since its inception, CAWEP has functioned to solve these issues and made a significant impact. New regional projects have been launched. Moreover, governmental strategies have been developed related to dam safety, climate change etc.

Consequently, it is noteworthy to demonstrate the success of the previous phases of CAWEP. First of all, more than 13,000 Uzbekistani and Tajikistani farmers have been able to carry out climate-smart activities and enhance their crop production. This is performed, certainly, with the support of a climate change adaptation and mitigation project in the Aral Sea Basin. Secondly, 87 weather stations and 19 river stations were successfully restored in Kyrgyzstan and Tajikistan. This has resulted in precision of weather forecasts in given countries by up to 30 percent under the Central Asia Hydrometeorology Modernization project. Thirdly, in Tajikistan the Nurek rehabilitation project was developed in the framework of CAWEP. The Nurek hydroelectric plant, which operates at just 77 percent, will endure major overhauls and expand winter output by 33 million $\mathrm{kWh}$. Finally, the Central Asian Youth for Water Network was created. This establishment currently brings together students and practitioners worldwide, assisting scientists to find solutions to the most emergent problems in their countries (World Bank press release, 2019).

The work plan for 2019 included 27 projects: 9 - under the component "Water Security", 9 under the component "Energy Security", 7 - under the component "Water and Energy Links", as well as supporting activities for program management and communications. CAWEP is implemented taking into account the findings of the previous phases of the program and pays special attention to activities at the national level as components of regional security. Technical and policy dialogue at the regional level, coupled with capacity building, remain important drivers of cooperation.

In 2019, following the EU contribution, CAWEP has allocated another US $\$ 6.48$ million, i.e. total funding increased to US \$ 8.76 million. In 2019, 27 grants were supported, the implementation of 5 of which was started during the 2019 calendar year. One grant was completed in 2019. In 2019, the first recipient-executable grant was approved under the Energy Security component (Tajikistan).

Payments in 2019 amounted to USD 1.3 million ( $15 \%$ of total funding). Currently, funding is distributed as follows: Water Security $-41 \%$, Energy Security - 22\%, Water and Energy Links 29\%, Program Management and Communications $-8 \%$. Payments at the end of 2019 exceeded USD 2.0 million (23\% of total funding) (CAWEP Annual report, 2019).

Central Asian governments are aware of the challenges and issues associated with the water and energy, environment and climate change at the national and regional levels. Accordingly, states came up with reforms, state and regional strategies.

In 2019 a new Ministry of Ecology, Geology and Natural Resources was created in Kazakhstan with the mandate to deal with water management issues. 
The new ministry is tasked with improving water management processes and combating poaching and deforestation. To this end, a Water Resources Management Program until 2030 and a new Environmental Code are being developed. Several international events took place in Kazakhstan during the year. At one of the sessions of the XII Astana Economic Forum, held in May in Nur-Sultan, "Water as a factor of economic growth and security in Central Asia", moderated by the Swiss Special Envoy for Water Resources in Central Asia. The head of the World Bank Office in Kazakhstan stressed that the economies of Central Asia do not experience a shortage of water resources, but they are far from using their water potential to the full. During the Second Central Asian Expert Forum on the topic "Dialogue on water issues in Central Asia: through the national to the region-wide", held on September 5 in Nur-Sultan, the role of regional cooperation in solving water and energy problems was discussed. The first regional summit on mobilizing funds for the implementation of the Sustainable Development Goals, which was held in November in Almaty, focused on strengthening water, energy and climate resilience, attracting private capital and mobilizing international resources to accelerate the achievement of the Sustainable Development Goals (CAWEP Annual report, 2019).

According to Gaukhar Beiseeva, Deputy Head of the International Center for Green Technologies and Investment Projects "water resources for Kazakhstan are in the first place in the transition to a green economy." The Concept for the transition to a "green" economy defines terms and target indicators. The goal is to eliminate water scarcity at the national level. By 2020, the main indicator is the provision of water to the population, by 2030 - the full provision of water to agriculture and by 2050 - once and for all solution of the problem with water supply. As she noted, based on the experience of the European Union, Kazakhstani experts should determine the possibilities of using the most accessible technologies. "Today's experience that we use is the creation of technology reference books as part of the implementation of the best available technologies. These are technologies that help to reduce the negative impact on the environment. We took this experience from the European Union. For 30 years, the EU first developed directives, and on the basis of them, special technological manuals were created, which clearly state what technology, what management and production process should be applied in order for the company not to pollute the environment", - said the deputy head of the Center Green technologies. Meanwhile, the head of the cooperation department of the EU Delegation to Kazakhstan Johannes Stenbek Madsen expressed that Europe intends to offer specific proposals to Central Asia to improve the quality of water resources (KazInform, 2019).

Moreover, Kazakhstan decided to transit to a green economy model, as announced in the country's 2050 Strategy (December 2012) and further detailed in the government's Green Economy Concept (adopted in May 2013) which proposes a comprehensive set of sustainabledevelopment initiatives in six priority sectors, such as water resources, agriculture, energy efficiency, power sector, air pollution, and waste recycling. It also must be noted that Kazakhstan has also established a multi-stakeholder, cross-sectoral and voluntary Green Bridge partnership program. This is done in order to ensure a sustainable and longterm framework for green investment, transition of new technologies and innovations to establish a sustainable economy, create new and long-term green jobs and achieve the Sustainable Development Goals (Green Economy: realities and prospects in Kazakhstan, 2018).

In July, the State Agency for Water Resources was created in Kyrgyztsan, the main objectives of which are to introduce an Integrated Water Resource Management (IWRM) mechanism, ensure rational water use and develop effective interstate cooperation. The Department of Water Management and Land Reclamation and the Department for Development of Drinking Water Supply and Sanitation have been transferred to the new agency. In November, at the forum "Accelerating Reforms for Sustainable Development", which was opened by the President of the Kyrgyz Republic Sooronbai Jeenbekov, priority development directions, including IWRM and climate change, were discussed. A draft National strategy for the development of the fuel and energy complex until 2030 has been developed (CAWEP, 2019).

Key priorities of the Kyrgyz Government's programme include reforming policy making and legislation through use of the Strategic Environmental Assessment and wider public participation, development of national policy on climate change, safeguarding biodiversity and rational use of natural resources and developing international cooperation to resolve national ecological problems. The National Sustainable Development Plan adopted in December 2013 includes measures for mitigating 
impact and reducing ecological consequences of economic activities; improvement of (drinking) water supply and sanitation, and measures on disaster risk reduction and management. The Government of Kyrgyzstan is in the process of adopting the National Strategy 2040 and associated five-year programme. These will reflect the country's socio-economic, political changes and transformations that have taken place since last years, and address issues relevant to the Sustainable Development Agenda 2030. This strategy acknowledges the importance of environmental approaches as a guiding principle for all measures taken and policies for the country development. The significance of the development of water (irrigation and drinking water sectors) is acknowledged to be an impactful outcome for the country's economic and environmental development, and eradicating food insecurity and malnutrition at large (Action Document for Sustainable Environment, Water and Energy Development, 2019).

In April, Tajikistan's government agreed on a six-year financial recovery program "Barki Tojik" (the national energy company) to improve its efficiency and financial sustainability, and the long-awaited project to expand and modernize the Nurek Hydroelectric Power Station was launched. The modernization will include the technical rehabilitation of three hydraulic units, the replacement of six autotransformers and the introduction of advanced safety procedures. In September, the second turbine of the Rogun Hydroelectric Power Station was commissioned. As a member of the UN High Level Panel on Water, Tajikistan convened a parallel meeting during the 74th session of the UN General Assembly in New York, dedicated to transforming action on water to accelerate the achievement of climate change goals at the global level. This event provided an opportunity to highlight the achievements in water management and climate change and provide participants with up-to-date information on the implementation of the International Decade for Action "Water for Sustainable Development" (2018-2028) (CAWEP Annual report, 2019)

In 2007, the Government of Tajikistan adopted the Concept of Transition of the Republic of Tajikistan towards Sustainable Development until 2030. In 2008, the Government approved the "Environmental Concept" aimed at rational use of natural resource. An Action plan for implementation was approved in 2010. The Government of Tajikistan is particularly involved in the water sector: at the end of 2015 the Programme of Water Sector Reform in Tajikistan for 2016-2025 was approved. This programme delineates the institutional and operational framework required to implement Integrated Water Resources Management (IWRM). In line with the Plan of Action of the UN High Level Panel on Water, Tajikistan initiated the UN General Assembly draft resolution to declare the period of 2018-2028 as the International Decade of Action "Water for Sustainable Development", which was adopted by consensus on 21 December 2016. The decision to build the Rogun Dam is a major undertaking for the country and is expected to significantly improve energy supply while there are some question marks about macroeconomic implications and environmental concerns. During the recent visit of Uzbek President Shavkat Mirziyoyev to Tajikistan on 9-10 March 2018 an agreement was reached on Uzbekistan's participation in the Rogun Dam project (Action Document for Sustainable Environment, Water and Energy Development, 2019).

In April, Ashgabat hosted bilateral discussions initiated by the Turkmen-Afghan coordination group on water issues with the aim of developing a mutually acceptable mechanism for the integrated and balanced use of transboundary water resources. Such a mechanism should be created in accordance with generally recognized norms and principles of international law and taking into account the interests of all countries in the region. In November, Turkmenistan organized and held an international conference "Rational use of water resources - the basis for achieving the Sustainable Development Goals", at which the Global Water Partnership presented its Strategy for 2020-2025 (CAWEP Annual report, 2019)

In Turkmenistan, the new Water Code has been elaborated introducing the principles of the IWRM. The country's economy is largely based upon the production and export of gas. Since 2017, the Executive Committee of IFAS has been located in the capital of Turkmenistan, Ashgabat, and is foreseen to remain there until August 2019. The country is a strong promoter of the organisation and its objectives (Action Document for Sustainable Environment, Water and Energy Development, 2019).

Speaking about the actions taken by Uzbekistan's government, on the basis of medium and long-term goals and agreed priority directions of development, the Water Strategy for the period up to 2030 is being developed. Presidential decrees were adopted 
on: (i) efficient use of land and water resources in agriculture; (ii) improving water resources management; and (iii) the agricultural development strategy for 2020-2030. In February, a Ministry of Energy was created to integrate the oil and gas and energy sectors. In March, the President adopted a resolution "On the strategy for further development and reform of the electric power industry of the Republic of Uzbekistan." In April, a reform of tariffs for electricity and water was initiated and a new procedure for setting tariffs was adopted. This is a significant step towards achieving a full return on the cost of organizing urban water supply, based on multi-year investment planning. As a result of the reorganization of Uzbekenergo JSC, three new joint-stock companies were created: Thermal Power Plants, National Electric Grids of Uzbekistan and Regional Electric Grids.

In October, a strategy for Uzbekistan's transition to a "green economy" until 2030 was approved. This will ensure that commitments under the Paris Climate Agreement are met, prioritization of energy efficiency, renewable energy development, and climate change adaptation coordination. In November, the Ministry of Housing and Communal Services was entrusted with the task of keeping records of water resources (CAWEP, 2019)

In parallel to the multitude of national strategies and policy documents, there is a growing recognition among CA governments that national approaches are insufficient to address the complex water, environment and energy challenges, many of which are transboundary by nature. On 30 January 2018, the Board of the International Fund for saving the Aral Sea (IFAS) passed a resolution to develop the fourth edition of the Aral Sea Basin Programme (ASBP). As a result, CA partners have expressed interest to foster cooperation with the European Union to benefit from European experiences and know-how
(Action Document for Sustainable Environment, Water and Energy Development, 2019).

\section{Conclusion}

The EU Strategy for Central Asia provides a framework for enhanced cooperation and an increasingly regional approach to foster integrated and efficient resources management. This has taken the shape of various programmes and projects implemented by EU in CA countries. The Central Asia Water and Energy Program (CAWEP) aims to create conditions for enhancing energy and water security at the regional level and in the beneficiary countries through increased cooperation. CAWEP promotes energy and water security by working to build the capacity of national institutions and improve performance across sectors, while supporting regional cooperation and dialogue to promote energy and water security at the national and regional level. The program is being implemented in cooperation with governments, which allows it to take into account national priorities in its activities. In their turn, Central Asian states develop strategies and documents at the governmental level. CAWEP funds initiatives to improve water and energy management processes, develop and strengthen national and regional institutions, and promote regional dialogue on water and energy security. The program helps realize the benefits of regional cooperation for sustainable development and increased resilience to climate change. In the framework ofCAWEP, a lot of measures were carried out by Central Asian states. Moreover, CAWEP continues to work with development partners to expand work to create conditions for deepening cooperation at the technical and institutional levels, strengthening existing databases and information, and harmonizing industry policies and regulations.

\section{References}

Action Document for Sustainable Environment, Water and Energy Development - European Union-Central Asia Water, Environment and climate change Cooperation (WECOOP) and the Central Asia Energy Water Development Programme (CAEWDP 1) [electronic source]. Retrieved from https://ec.europa.eu/international-partnerships/system/files/aap-financing-central-asiaannex2-c-2018-7651_en.pdf

Berndtsson R., Tussupova K. (2020) The future of water management in Central Asia. MDPI.

CAWEP Annual report, 2019 (World Bank Library) [electronic source] Retrieved from http://pubdocs.worldbank.org/ en/864641567759267834/CAWEP-Brochure-2019-ru.pdf

Green economy: realities and prospects in Kazakhstan (Samruk Kazyna document). [electronic source] Retrieved from https:// www.sk.kz/upload/iblock/8d9/8d97878e7ec2466e04ab62e5d8f4c3a3.pdf

Janusz-Pawletta B., Gubaidullina M. (2015) Transboundary Water Management in Central Asia. Legal Framework to Strengthen Interstate Cooperation and Increase Regional Security. Cahiers d'Asie centrale, N 25: 195-215 
Kazakhstan zaimstvuyet opyt Yevrosoyuza po uluchsheniyu kachestva vodnykh resursov [Kazakhstan adopts the experience of the European Union to improve the quality of water resources] [electronic source]: Retrieved from https:// www.inform.kz/ru/kazahstan-zaimstvuet-opyt-evrosoyuza-po-uluchsheniyu-kachestva-vodnyh-resursov_a3537189 Russian)

Menga F. (2018) Power and Water in Central Asia. Routledge.

New European Union seven million euro grant to strengthen water and energy security in Central Asia (World Bank press release dared 23 May 2019) [electronic source] Retrieved from https:/www.worldbank.org/en/news/press-release/2019/05/23/neweuropean-union-seven-million-euro-grant-to-strengthen-water-and-energy-security-in-central-asia

Paramonov V., Strokov A. (2015). The main problems on the way of cooperation in Central Asia: foreign policy forecast for regional countries. Journal "Central Asia \& Caucasus" (Stockholm, Sweden), 1(16): 58-77

Yezhegodnik: voda v tsentral'noy Azii i v mire 2019 [Yearbook: Water in Central Asia and the World 2019] [electronic source]. Retrieved from http://cawater-info.net/yearbook/1index.htm (In Russian) 